\title{
A Drosophila model linking diet-induced metabolic disease and cancer
}

\author{
Susumu Hirabayashi ${ }^{1 *}$, Thomas Baranski ${ }^{2}$, Ross Cagan ${ }^{1}$ \\ From Metabolism, Diet and Disease 2014: Cancer and metabolism \\ Washington DC, USA. 28-30 May 2014
}

\section{Background}

Epidemiological studies have provided strong evidence for the association between cancer and metabolic diseases including obesity and diabetes, but the underlying mechanism remains poorly understood.

\section{Methods}

Feeding Drosophila a diet high in sucrose was previously demonstrated to direct important aspects of type 2 diabetes including insulin-resistance, hyperglycemia, increased insulin levels, accumulation of fat, and heart dysfunction $[1,2]$. We used this model to explore the effects of high dietary sucrose on tumor progression of Ras/Src co-activated Drosophila tumor model.

\section{Results}

We demonstrate that high dietary sucrose, but not high dietary fat transforms Ras/Src-activated cells from localized growths to aggressive tumors with emergent metastases. Surprisingly, while most tissues displayed aspects of metabolic dysfunction including insulin resistance, Ras/Src-activated tumors retained insulin pathway sensitivity and exhibited an increased ability to import glucose. We provide evidence that this reflects increased insulin signaling, which in turn acts through Wingless/ Wnt signaling to promote diet-mediated malignant phenotypes within Ras/Src-activated tumors [3]. These fly models should provide useful paradigms to study the link between metabolic dysfunction and tumorigenesis in the context of a whole animal.

\footnotetext{
Authors' details

'Department of Developmental and Regenerative Biology, Icahn School of Medicine at Mount Sinai, New York, NY 10029, USA. ²Department of
}

'Department of Developmental and Regenerative Biology, Icahn School of Medicine at Mount Sinai, New York, NY 10029, USA

Full list of author information is available at the end of the article
Medicine, Washington University School of Medicine, St. Louis, MO 63110, USA.

Published: 28 May 2014

References

1. Musselman LP, Fink JL, Narzinski K, Ramachandran PV, Hathiramani SS, Cagan RL, Baranski TJ: A high-sugar diet produces obesity and insulin resistance in wild-type Drosophila. Dis Model Mech 2011, 4:842-849.

2. Na J, Musselman LP, Pendse J, Baranski TJ, Bodmer R, Ocorr K, Cagan R: A Drosophila model of high sugar diet-induced cardiomyopathy. PLOS Genet 2013, 9:e1003175.

3. Hirabayashi S, Baranski TJ, Cagan RL: Transformed Drosophila cells evade diet-mediated insulin resistance through wingless signaling. Cell 2013, 154:664-675

\section{doi:10.1186/2049-3002-2-S1-019}

Cite this article as: Hirabayashi et al:: A Drosophila model linking diet-induced metabolic disease and cancer. Cancer \& Metabolism 2014 2(Suppl 1):019.
Submit your next manuscript to BioMed Central and take full advantage of:

- Convenient online submission

- Thorough peer review

- No space constraints or color figure charges

- Immediate publication on acceptance

- Inclusion in PubMed, CAS, Scopus and Google Scholar

- Research which is freely available for redistribution

Submit your manuscript at www.biomedcentral.com/submit
() Biomed Central

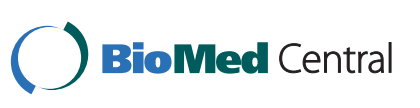

